\section{(- OPEN ACCESS}

\title{
Recurrent chikungunya retinitis
}

\author{
Silvia Olivia Salceanu, Vasant Raman
}

University hospitals of Plymouth, Royal Eye Infirmary, Derriford, Plymouth, UK

\section{Correspondence to \\ Mr Vasant Raman} vasant.raman@nhs.net

SOS and VR are joint first authorship.

Accepted 2 July 2018

Check for updates

(c) BMJ Publishing Group Limited 2018. Re-use permitted under CC BY-NC. No commercial re-use. See rights and permissions. Published by BMJ.

To cite: Salceanu SO, Raman V. BMJ Case Rep Published Online First: [please include Day Month Year]. doi:10.1136/bcr-2017222864

\section{SUMMARY}

Chikungunya is a systemic viral disease transmitted to humans by infected mosquitoes in endemic areas of Africa, Asia and more recently in the Americas. Chikungunya infection produces a sudden onset of fever, joint pains and erythematous skin eruption. A plethora of ocular manifestations have been described ranging from a non-specific conjunctivitis to exudative retinal detachment. Ocular chikungunya seems to respond well to corticosteroid therapy, and outcomes are usually better if treated early. Our patient acquired this infection on a travel to Mexico jungle. This was confirmed by ReverseTranscriptase-PCR test once she returned to the UK. The peculiarity of the case is the inordinate delay of almost a year in the onset of eye symptoms, from acquiring the viral infection. The ocular inflammation responded to systemic corticosteroid therapy with a favourable visual outcome. She developed a recurrence many months later which again responded well to a course of oral steroids.

\section{BACKGROUND}

A patient presented with unusual retinal findings and the aetiology was not clear initially. A detailed history and investigations pointed to the causative agent as the aetiological diagnosis. This report emphasises the extreme rarity of this case. With international travel becoming widespread, it is important to spread awareness in the ophthalmology community.

\section{CASE PRESENTATION}

A 26-year-old white British woman travelled to Mexico in August 2015 and developed chikungunya infection while touring a jungle area. The infection was confirmed by a local doctor, as the patient had the classic chikungunya symptoms of fever, joint pain and skin eruption. On returning to the UK, the patient consulted a rheumatologist for having persistent joint pains. Chikungunya infection was confirmed by RT-PCR in November 2015. All other possible rheumatological diseases were excluded by further tests. Chest X-ray, Anticnuclear antibody (ANA), anti nuclear cytoplasmic antibody (ANCA) rheumatoid factor, full blood count and $\mathrm{C}$ reactive protein were normal.

In July 2016, the patient presented to the urgent care department in ophthalmology with gradual loss of vision in her left eye for the past 1 week. Her Snellen visual acuity was $6 / 6$, right eye, and $6 / 12$, left eye. Ocular examination of the right eye was normal. In the left eye, anterior segment examination and intraocular pressure by
Goldmann applanation tonometry were normal. There was no afferent pupillary defect. Posterior segment examination revealed an inflammatory foveal lesion (figure 1). High-definition Optical coherence tomography (OCT) scan of the left eye showed increased reflectivity of the neurosensory retina with a cleft of underlying subretinal fluid (figure 2). Angio-OCT scan showed areas of capillary dropout on the nasal aspect of the foveal avascular zone (figure 3). Fluorescein angiography (figure 4) showed an area of leakage in the fovea suggesting focal foveal capillary vasculitis, whereas indocyanine green (ICG) angiography (figure 5) failed to show active choroidal inflammation.

The patient was not on any medication, and there was no ocular history of relevance.

\section{INVESTIGATIONS}

Systemic: RT-PCR for chikungunya virus. Chest X-ray, ANA, ANCA rheumatoid factor, full blood count and $C$ reactive protein.

Serological test for HIV, syphilis, tuberculosis, Lyme disease, toxoplasma and toxocariasis.

Ocular investigation: Fundus Fluorescein angiography (FFA), ICG and OCT-angiography.

\section{DIFFERENTIAL DIAGNOSIS}

Viral (herpetic) retinitis, HIV retinopathy, toxocara, toxoplasma and Lyme disease-related retinitis.

\section{TREATMENT}

Oral steroids_-prednisolone $1 \mathrm{mg} / \mathrm{kg}$ body weight in a tapering dose.

\section{OUTCOME AND FOLLOW-UP}

Good visual recovery, with OCT evidence of minimal structural damage to the area of focal retinal inflammation (figure 6). The patient relocated to a different country following the initial treatment. The patient's treating physician was contacted a few months later to know the course of her ocular condition. We were informed about the recurrence of her retinitis (figure 7) and the good response to a repeat course of oral steroids.

\section{DISCUSSION}

Chikungunya is a systemic viral infection transmitted to humans by the bite of infected female mosquitoes (Aedes aegypti and Aedes albopictus spp). It has a wide variety of presentations, ranging from conjunctivitis to exudative retinal detachment. ${ }^{1-7}$ Non-granulomatous and granulomatous 


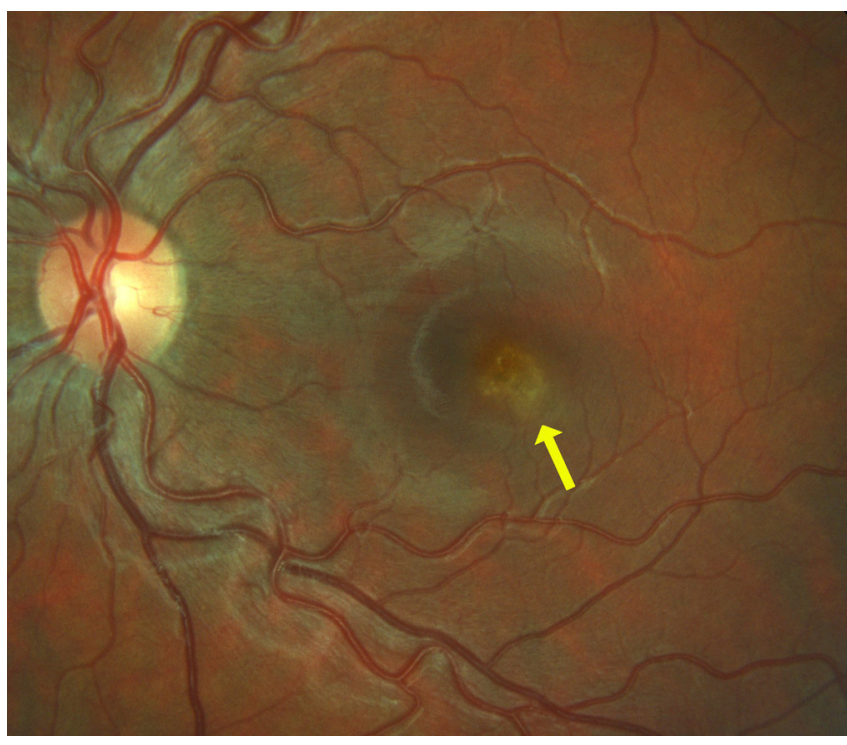

Figure 1 Focal whitening (yellow arrow) of the retina around the fovea.

anterior uveitis is the most common presentation of chikungunya eye disease. ${ }^{6}$ To the best of our knowledge, this is the first case of presumed chikungunya foveal retinitis in the UK and in Europe. Most reported cases of chikungunya retinitis are from the Indian subcontinent. Several studies have confirmed direct infection with chikungunya virus by performing PCR analysis of anterior chamber tap in patients with acute anterior uveitis. ${ }^{4}$

In our patient, there was no anterior chamber activity so we were reluctant to perform an anterior chamber tap. The presence of rheumatological features in the patient with a positive RT-PCR test, coupled with a negative serology for other arthropathies strongly indicates infection with chikungunya virus. The pathogenesis of retinitis although speculative, probably represents a focal vasculitis. Further, angiographic evidence of focal ischaemia in the FAZ is suggestive of an occlusive vasculitis. If this is the case, then antiplatelet agent may have a role, in addition to systemic steroids. The fluorescein angiogram and OCT-angio picture are suggestive of a primary vascular involvement of the neurosensory retina. Mahesh et $a l^{5}$ describe a case of bilateral chikungunya neuroretinitis but their patient presented 2 weeks after the onset of systemic

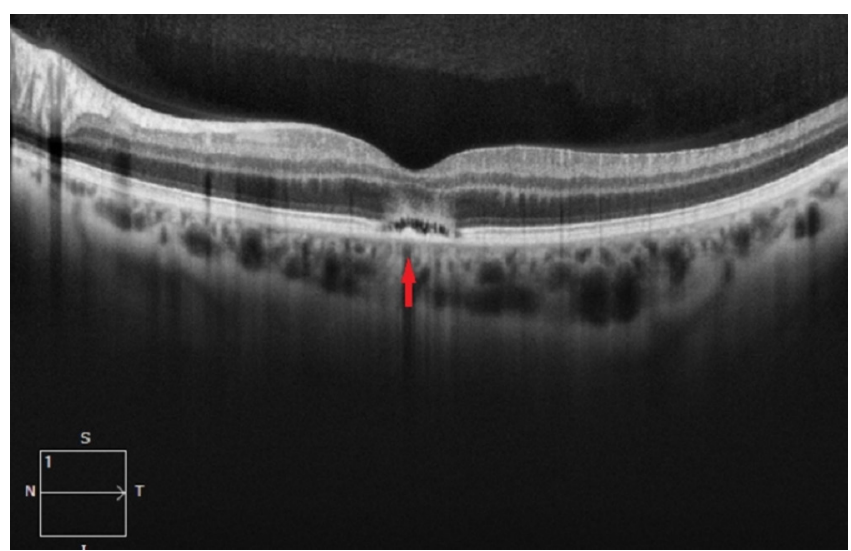

Figure 2 High-definition OCT scan: left eye (red arrow) showing focal area of retinitis with a small cuff of SRF. SRF, Sub retinal fluid.
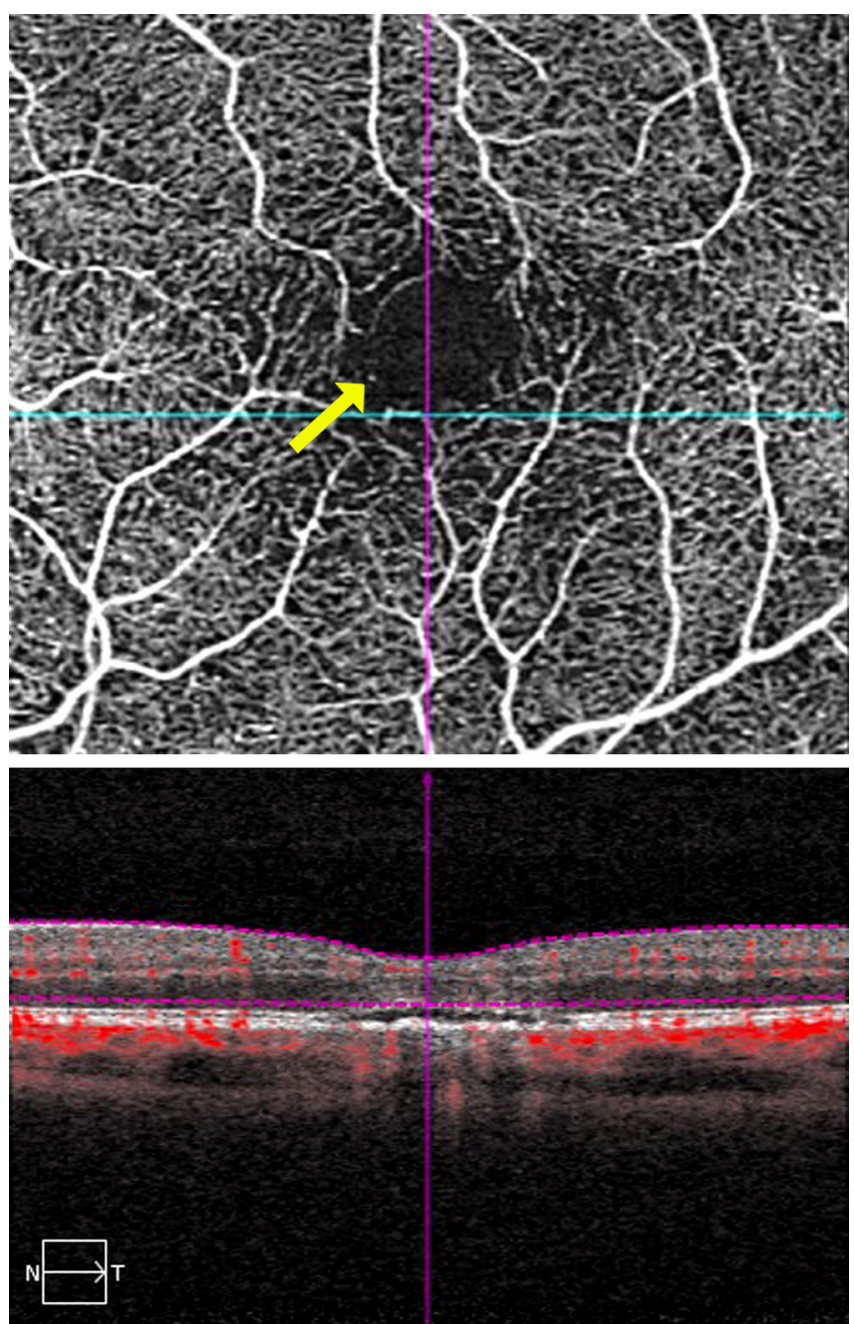

Figure 3 OCT-angio: arrow showing focal capillary dropout in nasal FAZ. FAZ, Foveal avascular Zone.

symptoms. Most of the reported cases of retinitis were within few weeks of the systemic symptoms, but our case was peculiar in that the ocular manifestation was delayed by almost a year. CD4+ Tlymphocyte-mediated cell response has been implicated during the later stage of the disease. Interleukin-12, which returns to normal level following the acute phase in
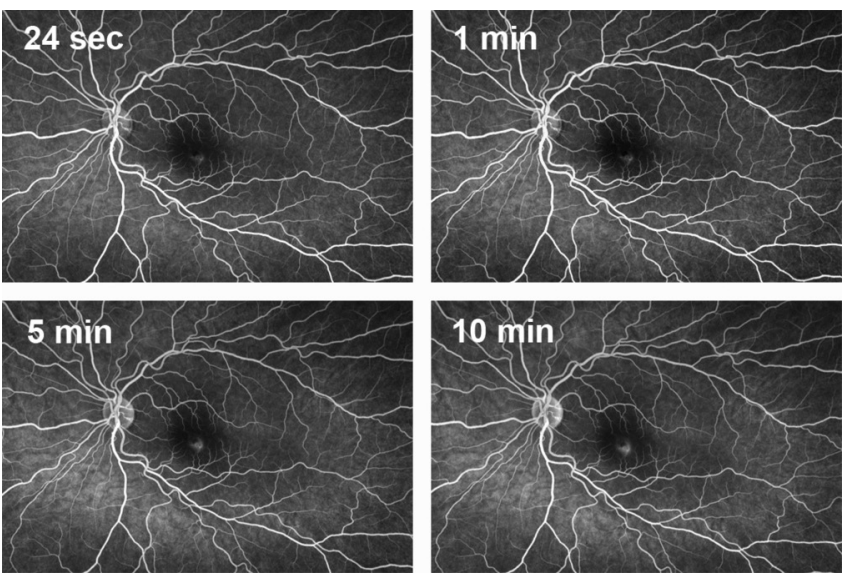

Figure 4 Fluorescein angiogram showing minimal leakage during the later frame of the angiogram. 


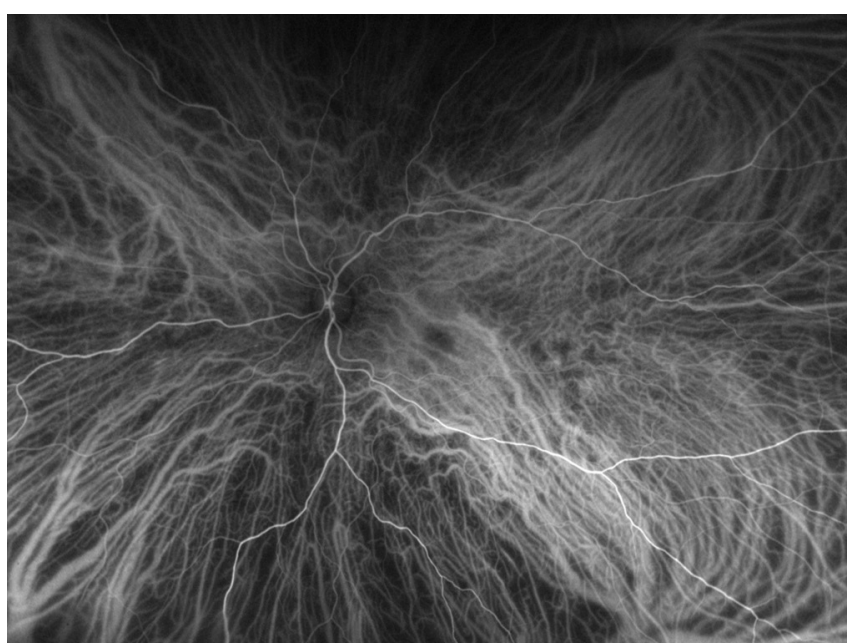

Figure 5 Normal indocyanine green angiogram.

chikungunya virus infection, is elevated if patients develop chronic arthritis. Matrix mettaloproteinase (MMP-2) has also been implicated in tissue damage. With a delayed ocular presentation and persistent joint symptoms in our patient, the above cytokines probably played a part in the pathogenesis. The mechanism of the focal foveal retinitis in our patient would represent either a delayed immune-mediated response or a direct infection with chikungunya virus. The persistence of the virus for months and even years in the body has been established. ${ }^{8}$ Nevertheless, the molecular details of the pathogenesis remain speculative.

The majority of patients with chikungunya retinitis recover well over a 10 to 12 -week period, with a good visual outcome and only subtle retinal pigment epithelial alterations. ${ }^{6}$ This was also the case in our patient, whose visual acuity at last follow-up had improved to 6/6. Our case would suggest that chikungunya retinitis can present either early or quite late after acquiring the infection. The visual outcome nevertheless is good in either case if treated early with systemic steroids. The presence of chronic arthralgia may be a marker for recurrence of the eye disease as we see in our patient. It may be sensible to counsel the patient regarding the same. With international travel becoming more widespread, chikungunya infection should be considered in the differential diagnosis of retinitis, if the patient had visited an endemic zone. The retinal presentation could be either unilateral or bilateral, and the vitreous may or may not be involved as we see in our case. In the UK, a

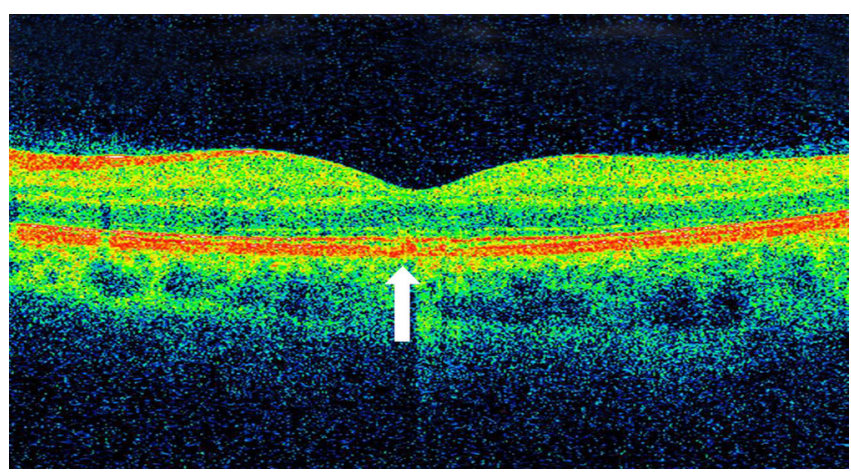

Figure 6 SD-OCT: resolved retinitis with mild disruption of RPE/ photoreceptor complex. OCT, optical coherence tomography; RPE, retinal pigment epithelium; SD, spectral domain.

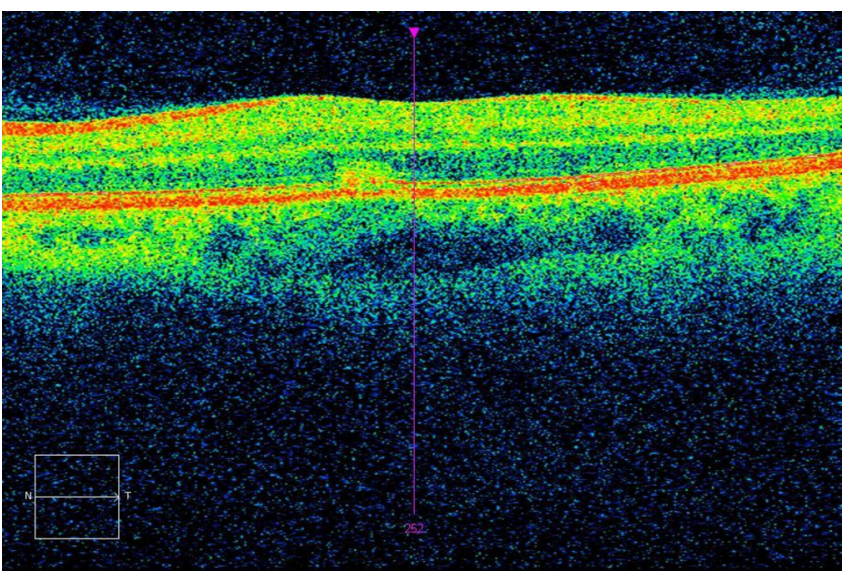

Figure 7 Recurrence of retinitis. Note hyper-reflectivity of the outer retina near the cursor.

case of optic neuritis with poor visual outcome due to chikungunya was reported in a 69-year-old patient who travelled to the West Indies. ${ }^{2}$ A French article describes conjunctivitis in a 31-year-old patient with severe chikungunya infection returning from Mayotte, French Comoros. ${ }^{7}$ To the best of our knowledge, there are no other chikungunya eye-related cases published in Europe.

\section{Learning points}

- Chikungunya retinitis should be considered in the differential diagnosis of patients with focal retinitis giving a history of international travel, particularly to endemic areas.

- Oral steroid should be instituted soon, as the outcome is usually good if done early.

- Possibility of recurrence of the retinitis should be explained to the patient.

- Persistent arthralgia may be a marker of recurrence of retinitis.

Acknowledgements We wish to thank Dr. Stephen guest of Hamilton eye clinic in New Zealand for providing details of management of the patient when she was under his care.

Contributors Both the authors have contributed equally to the concept, design and writing up of this case report. Both of us would like to be first authors and myself (VR) as the corresponding author. The signed authorship document is enclosed.

Funding The authors have not declared a specific grant for this research from any funding agency in the public, commercial or not-for-profit sectors.

Competing interests None declared.

Patient consent Obtained.

Provenance and peer review Not commissioned; externally peer reviewed.

Open access This is an open access article distributed in accordance with the Creative Commons Attribution Non Commercial (CC BY-NC 4.0) license, which permits others to distribute, remix, adapt, build upon this work non-commercially, and license their derivative works on different terms, provided the original work is properly cited and the use is non-commercial. See: http://creativecommons.org/ licenses/by-nc/4.0/

\section{REFERENCES}

1 Scripsema NK, Sharifi E, Samson CM, et al. Chikungunya-associated uveitis and exudative retinal detachment: A case report. Retin Cases Brief Rep 2015;9:352-6.

2 Mohite AA, Agius-Fernandez A. Chikungunya fever presenting with acute optic neuropathy. BMJ Case Rep 2015.doi: bcr2015210081.

3 Vishwanath S, Badami K, Sriprakash KS, et al. Post-fever retinitis: a single center experience from south India. Int Ophthalmol 2014;34:851-7. 
4 Babu K, Kini R, Philips M, et al. Clinical profile of isolated viral anterior uveitis in a South Indian patient population. Ocul Immunol Inflamm 2014;22:356-9.

5 Mahesh G, Giridhar A, Shedbele A, et al. A case of bilateral presumed chikungunya neuroretinitis. Indian J Ophthalmol 2009:57:148-50.

6 Mahendradas P, Avadhani K, Shetty R. Chikungunya and the eye: a review. J Ophthalmic Inflamm Infect 2013;3:35.
7 Parola P, de Lamballerie X, Jourdan J, et al. Novel chikungunya virus variant in travelers returning from Indian Ocean islands. Emerg Infect Dis 2006;12:1493-9.

8 Hawman DW, Stoermer KA, Montgomery SA, et al. Chronic joint disease caused by persistent Chikungunya virus infection is controlled by the adaptive immune response. $J$ Virol 2013;87:13878-88

Copyright 2018 BMJ Publishing Group. All rights reserved. For permission to reuse any of this content visit http://group.bmj.com/group/rights-licensing/permissions.

BMJ Case Report Fellows may re-use this article for personal use and teaching without any further permission.

Become a Fellow of BMJ Case Reports today and you can:

- Submit as many cases as you like

- Enjoy fast sympathetic peer review and rapid publication of accepted articles

- Access all the published articles

Re-use any of the published material for personal use and teaching without further permission

For information on Institutional Fellowships contact consortiasales@bmjgroup.com

Visit casereports.bmj.com for more articles like this and to become a Fellow 